\title{
Do Shariah-compliant Companies Engage Lesser Earnings Management Behaviour?
}

\author{
Ibrahim Mohd Sabrun*, Rusnah Muhamad, \\ Haslinda Yusoff and Faizah Darus
}

\begin{abstract}
Manuscript type: Research paper.

Research aims: This study aims to understand how reputation, financial distress and financial performance influence Shariah-compliant companies into engaging earnings management behaviour. The financial data of 69 FTSE Bursa Malaysia 100 Index companies, dating 2010 to 2014 (five years), were analysed.

Design/ Methodology/ Approach: This study uses the Modified Jones model (Jones, 1991; Dechow, Sloan, \& Sweeney, 1996), Roychowdhury's model (2006) to examine earnings management behaviour of Shariah-compliant companies.

Research findings: The results of this study suggest that company's reputation, financial distress and financial performance are factors that can influence company's earnings management behaviour and that Shariah values are ineffective in deterring the management from earnings management behaviour.

Theoretical contribution/ Originality: The findings of this study contribute to the literature by showing that Shariah values may not
\end{abstract}

\footnotetext{
* Corresponding author: Ibrahim Mohd Sabrun is a PhD candidate at the Faculty of Business and Accountancy, University of Malaya, 50603 Kuala Lumpur, Malaysia. Email: imsabrun@ siswa.um.edu.my

Rusnah Muhamad is an Associate Professor at the Faculty of Business and Accountancy, University of Malaya, 50603 Kuala Lumpur, Malaysia. Email: rusnah@um.edu.my

Haslinda Yusoff is an Associate Professor at the Faculty of Accountancy, Universiti Teknologi MARA, 42300 Bandar Puncak Alam, Selangor, Malaysia. Email: hasli229@salam.uitm.edu.my Faizah Darus is a Professor and Dean at the Faculty of Accountancy, Universiti Teknologi MARA 42300 Bandar Puncak Alam, Selangor, Malaysia. Email: faiza634@salam.uitm.edu.my
}

The authors would like to express their gratitude to the Accounting Research Institute, Ministry of Education, Malaysia and MARA University of Technology for facilitating this research project. 
be beneficial in shaping good business management and reporting practices.

Practitioner/ Policy implications: The alarming results drawn from this study is a reason for policy setters and relevant accounting bodies to give more emphasis on developing better accounting and reporting policies.

Research limitation: This study is limited to non-financial sectors due to measurement limitations.

Keywords: Earnings Management, Financial Distress, Financial Performance, Fraud Diamond Theory, Reputation, Shariah-compliant JEL Classification: M41

\section{Introduction}

The global Islamic finance market value is experiencing rapid growth. In the year 2012, its value was USD1.2 trillion and expected to reach USD2.6 trillion in 2017 ( $\mathrm{PwC}, 2013)$. Malaysia aspires to become the leader in the global Islamic finance market. It established the Shariah Index in 1999, and the Islamic Financial Services Act was enacted in 2013. Further, the Securities Commission Malaysia (SC) reported that the Islamic capital market in Malaysia has grown at an average of 12 per cent per annum (SC, 2015). In 2014, the Malaysia Islamic Capital Market contributed RM1.59 trillion, an amount that is equivalent to 58 per cent of the RM2.76 trillion of the total Malaysia's capital market.

The goal of Islamic business practices is primarily, not about materialism. Instead, it is based on the concept of consumers' wellbeing and good life. It also stresses on social justice and the balancing of materials and spirituality (Rice, 1999). Scholars (e.g., Noreen, 1988; Kennedy \& Lawton, 1998; Longenecker, McKinney, \& Moore, 2004) believe that in general, religion is one of the mechanisms that helps an individual to refrain from unethical conduct especially in business operations.

Issues regarding earnings management and creative accounting have been extensively researched (Hossain, Karim, \& Eddine, 2014) since Enron's accounting scandal caused by earnings management behaviour (e.g., Gordon, 2002; Healy \& Palepu, 2003; Li, Pincus, \& Rego, 2008; Desai \& Dharmapala, 2009; Ibrahim, Darus, Yusoff, \& Muhamad, 2015). Ibrahim et al. (2015), for example, found that companies offering Islamic products and services tend to practise sustainability reporting, which are also less involved in earnings management behaviour. 
Based on the robust evidence, Wan Ismail, Kamarudin and Sarman (2015) noted that Shariah-compliant companies have significantly higher earnings quality. Nonetheless, there are studies which claim that companies that are significantly influenced by religion, specifically Islam, also performed unethical conducts including earnings management behaviour (e.g., Dyreng, Mayew, \& Williams, 2012; Alkdai \& Hanefah, 2012; Hamdi \& Zarai, 2012; Farooq \& AbdelBari, 2015; Alsaadi, Ebrahim, \& Jaafar, 2017). Omar, Koya, Sanusi and Shafie (2014) stated that Malaysian companies commit not only earnings management behaviour but fraudulent financial reporting. This implies that corporate governance mechanisms do not have much impact in curbing the practice of earnings management behaviour by companies (Mohamad, Abdul Rashid, \& Mohammed Shawtari, 2012; Abdullah, Halim, \& Nelson, 2014). Nonetheless, their studies did not distinguish between Shariah-compliant and non-Shariah compliant status.

To date, scholars are still debating as to whether earnings management behaviour is an act of manipulation or otherwise (e.g., Kaplan, 2001; Vinciguerra \& O'Reilly-Allen, 2004; Huang, Louwers, Moffitt, \& Zhang, 2008; Johnson, Fleischman, Valentine, \& Walker, 2012). Observations, however, indicate that the practice of earnings management behaviour and fraudulent financial reporting share some similar features one of which is the intent to deceive, a conduct motivated by private gains (Marai \& Pavlović, 2013).

The current study aims to examine the accounting practice behaviours of Shariah-compliant companies. Using 2010 to 2014 financial data of 69 FTSE Bursa Malaysia 100 Index companies, the present study aims to examine how company reputation, financial distress and financial performance can impact on the earnings management practices of Shariah-compliant companies. The main objective is to examine whether these Shariah-compliant companies which holistically practise Islamic principles, abstain from unethical and immoral behaviours in financial reporting practices.

The findings of this study may provide direction to regulators and other relevant accounting bodies to improve the quality of Islamic and Shariah accounting practices in Malaysia. This study may also enrich literature on Shariah as well as earnings management behaviour research.

The remainder of this paper is organised as follows: Section 2 reviews past literature and develops the hypotheses and theoretical framework. Section 3 explains the research methodology. Section 4 discusses the research findings and Section 5 concludes. 


\section{Literature Review and Hypotheses Development}

\subsection{Earnings Management and Financial Crisis}

During the 1997 Asian financial crisis, companies were found to be involved in earnings-decreasing activities (i.e., avoid reporting high profits) because these companies were expected to have "lower" earnings as a result of the crisis. Consecutively, companies with "lower" earnings were supported by government-aided financial assistance (Chia, Lapsley, \& Lee, 2007). It appears that such kind of behaviour was prevalent among companies (Jones, 1991). Countries in Europe were not exempted, for companies in these countries were also found to be indulging in earnings-increasing activities prior to the 2008 financial crisis. However, such activities decreased during the crisis (Filip \& Raffournier, 2014). A recent study (Franceschetti, 2018a) claimed that the financial crisis cannot be deduced to be the cause of earnings management behaviour among companies. This is because there is inadequate evidence to support the existence (Franceschetti, 2018a). Consequently, it is agreed that other factors could influence earnings management behaviour.

Despite Franceschetti's (2018a) claim, many researchers continue to assert that financial crisis plays a major role in causing earnings management behaviour amongst companies. These researchers and their findings, however, are not consistent. For instance, some studies were conducted independently with different sets of data involving different scenarios (Franceschetti, 2018b). Nevertheless, one study conducted by Wan Ismail et al. (2015) did find some evidence to suggest that there were differences in the earnings quality amongst Malaysian companies before and during the 2008 financial crisis. Their results, nonetheless, are different from Chia et al. (2007) and Filip and Raffournier (2014), but consistent with the notion that Islamic financing (i.e., equipped with Shariah guidelines and principles) is a better shield against financial crisis. Shariah values prevent unethical behaviours such as earnings management among the respective companies (Guyot, 2011).

\subsection{Earnings Management and Shariah-compliant}

Extant literature reveals that religion plays an important role in various matters including the promotion of good ethical behaviours amongst business organisations (e.g., Longenecker et al., 2004; Wan Ismail et al., 2015). In spite of this, recent studies examining financial reporting 
behaviours amongst Shariah-compliant companies noted that Islamic ethical values did not prevent the management from indulging in unethical conducts specifically, earnings management behaviour (Farooq \& AbdelBari, 2015; Alsaadi et al., 2017). In the business domain, earnings management occurs when managers use their judgement to manipulate their financial reporting by structuring transactions with the intent to mislead stakeholders about the company's real financial performance (Healy, 1985; DeAngelo, 1986; Schipper, 1989).

Some researchers note that certain earnings management behaviour is acceptable under conventional accounting standards (Bruns \& Merchant, 1990; Merchant \& Rockness, 1994; Parfet, 2000; Arya, Glover, \& Sunder, 2003). Other scholars regard earnings management behaviour as going against the value of religion (Ronen \& Yaari, 2008; Loomis, 1999; Grant, DePree Jr, \& Grant, 2000; Solomon, 1992; Rawls, 1972; Vladu, Amat, \& Cuzdriorean, 2017; Farrell, 2015; Abdullah et al., 2014). For instance, earnings management behaviour goes against the truthfulness of accounting (Ronen \& Yaari, 2008); it is intolerable (Loomis, 1999; Grant et al., 2000); it is immoral (Solomon, 1992) and it goes against the principle of justice (Rawls, 1972). The financial losses witnessed in Enron, WorldCom, Tyco International (Vladu et al., 2017), Olympus, Tesco (Farrell, 2015) and Satyam Computer Services (U.S. Securities and Exchange Commission (SEC), 2011) within the international front and Transmile and Megan Media in Malaysia (Abdullah et al., 2014) have all been linked, whether directly or indirectly, to issues of deception, misleading information and untruthful accounting.

Arguably, earnings management behaviour can be considered as a tool used by the management to run the business but Jones (2011) agreed that earnings management behaviour is a form of creative accounting. It is employed for the purpose of altering the accounting information that is reported to stakeholders. Such shenanigans are pursued so as to fulfil the management's desires. Consequently, stakeholders especially investors and financiers, are misled by the false information to make wrong decisions (Elliott \& Willingham, 1980). In that regard, it is clear that earnings management behaviour may lead to misinterpretation and misapprehension of data, particularly among the stakeholders. Further to this, scholars also believe that companies that are involved in earnings management behaviour have higher possibilities of committing fraud (Perols \& Lougee, 2011; Lee, Ingram, \& Howard, 1999).

Debates about whether earnings management behaviour is fraudulent or just a management tool to project good financial reports continue 
to exist among academicians. This is aptly pointed out by Du Jardin, Veganzones, and Séverin (2017, p. 5), "techniques that may be used to present financial statements more or less advantageously are essentially structured around earnings because this is the main variable that reflects firm performance, and any change that may affect accounting statements aims obviously at changing the way firm performance is perceived; this is the reason why these techniques are called earnings management". From the Islamic perspective, earnings management behaviour is considered as illicit (haram) because it is an act of deception to conceal the truth (Sheikh Obid \& Demikha, 2011).

A study conducted by Wan Ismail et al. (2015) examined the practices of 508 Malaysian companies before the 2008 financial crisis and found that Shariah-compliant companies have high earnings quality. According to Wan Ismail et al. (2015), Shariah-compliant companies have the tendency to report high earnings quality because they are subjected to greater scrutiny from their regulators. In other words, these companies have the duty of maintaining their reputation which promotes and practices Islamic ethical values. Drawing from Lo (2008), Weil (2009), Dechow, Ge and Schrand (2010), and Li, Abeysekera and Ma (2011), companies with high-quality earnings are less involved in earnings management behaviour.

However, Hamdi and Zarai (2012) provided evidence to show that Islamic banks around the world had managed their earnings so as to avoid reporting losses or reduced income because the negative reporting could harm the banks' reputation. Likewise, Farooq and AbdelBari (2015) found that companies in the Middle East and North Africa region which experienced financial distress committed earnings management behaviour. Therefore, it can be deduced that helming a Shariahcompliant company does not prevent its management from practising earnings management. Farooq and AbdelBari (2015) also noted that during the financial crisis of 2008, both the Shariah-compliant and nonShariah-compliant companies were similarly involved in earnings management behaviour.

It appears that such practices did not escape Europe. Focussing on Shariah-compliant companies in the European Union countries, Alsaadi et al. (2017) also observed that Shariah-compliant companies were involved in earnings management behaviour. Many possibilities can be cited for the phenomenon and one likelihood is the lack of regulation, enforcement and monitoring. Returning to the Malaysian context, one also raises the question of whether Malaysian companies were also 
involved in earnings management behaviour after the 2008 financial crisis. In Malaysia, the Shariah Advisory Council (SAC), under the Securities Commission of Malaysia (SC), screen public listed companies twice a year, i.e., in May and November and provide a list of Shariahcompliant companies in Malaysia. Companies found engaging in activities which are contrary to Shariah value would be removed from the list. Based on this, it can be deduced that the position of companies in Malaysia is different from that of companies in the European Union countries. Thus, the following hypothesis is posited:

$\mathrm{H}_{1}$ : Shariah-compliant companies are less likely to engage in earnings management.

\subsection{Earning Management and Reputation}

Using market capitalisation as an indicator for the company's reputation, researchers like Cao, Myers, and Omer (2012) found that companies with good reputation are less likely to misstate their financial statements; they are also less involved in earnings management behaviour. Aggressive earnings management and accounting scandals can harm the company's reputation (Zahra, Priem, \& Rasheed, 2005; Francis, Nanda, \& Olsson, 2008; Martínez-Ferrero, Banerjee, \& García-Sánchez, 2014). Being a Shariah-compliant company is one way of boosting the company's reputation. Such companies are expected to adhere to Islamic or Shariah values which are favoured by the society. Shariah-compliant companies are thus subjected to greater scrutiny by regulators and other stakeholders (Wan Ismail et al., 2015). Taking this as a possible way to gauge companies, this study aims to examine the effect a company's reputation may have in influencing the management into engaging with earnings management practices. Based on this, the following hypothesis is posited:

$\mathrm{H}_{2}$ : Reputation has a negative impact on earnings management practices in Shariah-compliant companies.

\subsection{Earnings Management and Financial Distress}

Various studies have been conducted to analyse earnings management behaviour amongst Shariah-compliant companies (Hamdi \& Zarai, 2012; Farooq \& AbdelBari, 2015; Wan Ismail et al., 2015; Alsaadi et al., 2017). However, these were carried out in different domains such as business 
operations, economic landscape and regulations. As a result of the differences, the findings were thus less consistent. Studies have shown that company management engages in earnings management behaviour as a way of avoiding the need to report company losses (Hamdi \& Zarai, 2012). This was observed during the financial crisis period where many companies tend to commit earnings management (Farooq \& AbdelBari, 2015). Such an occurrence implies that financial distress has an impact on management's decision-making with regards to earnings which seems to take precedence over ethical concern. The severity of a company's financial distress are also proven to have encouraged companies to engage in earnings management behaviour (Jaggi \& Lee, 2002) and to intentionally use such earnings management behaviour to write-off losses (Perez, Salas-Fumas, \& Saurina, 2008). Based on this, the following hypothesis is thus formulated:

$\mathrm{H}_{3}$ : Financial distress has a positive impact on earnings management practices in Shariah-compliant companies.

\subsection{Earnings Management and Financial Performance}

Extant literature suggests that earnings management behaviour is one of the consequences of better financial performances (e.g., Kim, Park, \& Wier, 2012; Ibrahim et al., 2015; Alsaadi et al., 2017; Wang, Cao, \& Ye, 2016; Ding, Li, \& Wu, 2018). This was also asserted by Orlitzky, Schmidt, and Rynes (2003, p. 408) who said that "indicators such as return on assets and return on equity are subject to managers' discretionary allocations of funds to different projects and policy choices, and thus reflect internal decision-making capabilities and managerial performance rather than external market responses to organizational actions." Therefore, earnings management behaviour may reflect the manager's interest and intention to showcase the company's financial performance (Hemingway \& Maclagan, 2004; Bansal \& Clelland, 2004). In their view, Alsaadi et al. (2017) mentioned that companies with better financial performances are more likely to engage in earnings management behaviour. They had specifically observed the influence of Shariah-compliant values and financial performance on earnings management behaviour of different organisations. Based on the above, the following hypothesis is formulated:

$\mathrm{H}_{4}$ : Financial performance has a positive impact on earnings management practices in Shariah-compliant companies. 


\subsection{Theoretical Framework}

Fraudulent financial reporting relates to deliberate fraud that is committed by management. This practice can bring financial harm to investors and creditors who make their decisions based on misleading financial statements (Elliott \& Willingham, 1980). Misleading financial statements are designed by company managers with the intent to deceive. The unethical behaviour may be accomplished by using fictitious documents and creating misrepresentations in the accounting reports (Pierre \& Anderson, 1984). Consequently, all that was presented in the reporting is a misrepresentation of reality (Wallace, 1995). Nevertheless, not all earnings management practices are considered as fraudulent. This encompasses earnings management behaviour that adheres to accounting standards.

To accomplish the aim of this study, a number of approaches were applied. First, this study uses the Fraud Diamond Theory to understand the inconsistency and mixed findings of earnings management practised amongst Shariah-compliant companies. The fraud diamond theory suggests that the perpetrator who commits a fraud is influenced by external and internal factors. Wolfe and Hermanson (2004) posited that unethical conduct happens due to the existence of incentive and/or pressure. The pressures may be financial problems, work problems or personal pressures.

The American Institute of Certified Public Accountants (AICPA) (2002) suggested that a manager is more likely to engage in an unethical behaviour when there is an opportunity, especially where internal control and monitoring are lacking. Such unethical behaviour or conduct is usually for self-benefit or company advantage. In contrast, a study by Septiari and Maruli (2017) showed that managers with high levels of professional commitment have a lower tendency to engage in unethical conduct. Some managers may have very good principles that hold him/her steadfast to his/her responsibilities while others may have reasons to justify their conduct. A rationalisation is an occasion where such managers are able to justify his/her unethical actions. For instance, the managers choose to ignore certain religious and ethical concerns by clinging to logic thereby, locating "a good reason" for doing a bad thing.

Wolfe and Hermanson (2004) focussed on managers' choice to ignore certain religious and ethical concerns by addressing their capability. These capabilities can be viewed from five descriptions. First, 


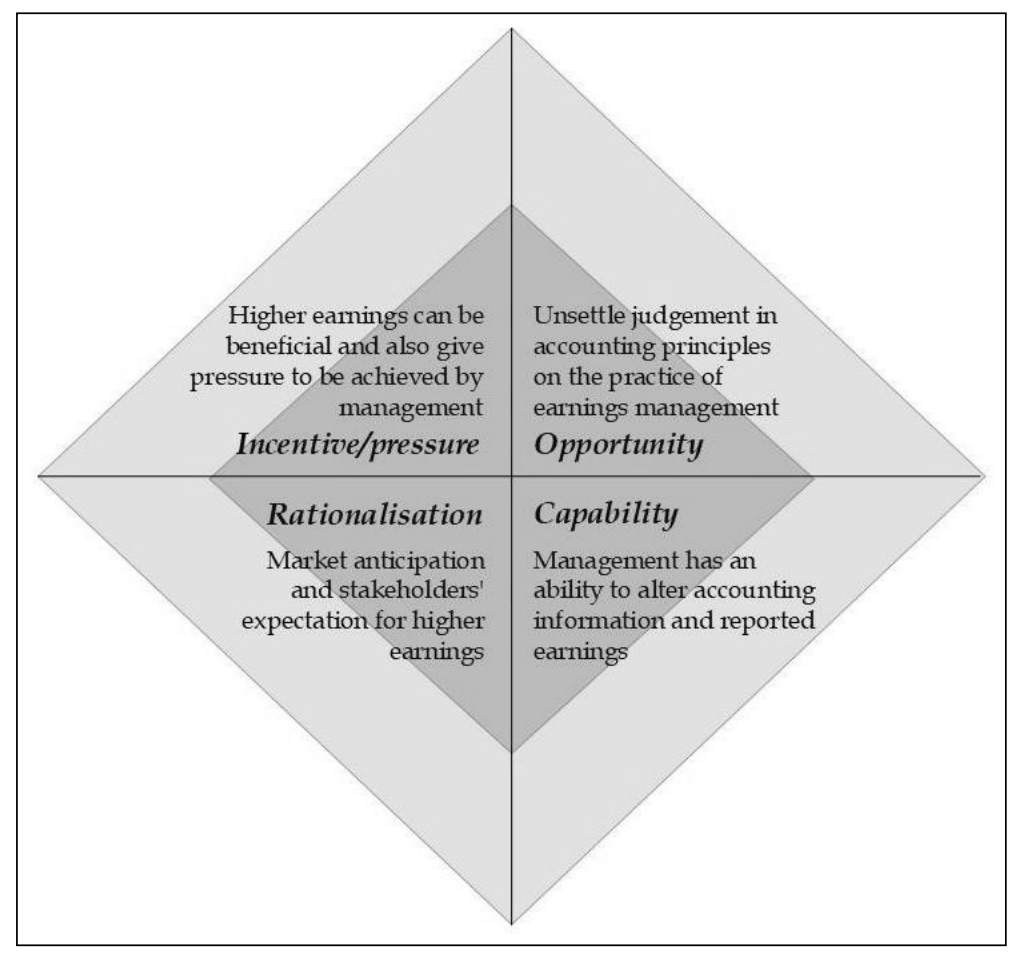

Figure 1: Fraud Diamond Theory on Earnings Management

Source: Self-illustrated based on Wolfe and Hermanson's (2004) theory.

the person with position within the organisation may find an opportunity to conduct an unethical behaviour. Second, the person who is smart in handling and exploiting the weaknesses of internal control and has authorised access to personal advantage is likely to conduct unethical behaviour. Third, a person who has strong confidence and ego thereby making him/her less suspected or detected is likely to conduct unethical behaviour. Fourth, a person who can coerce others to commit or conceal unethical matters is likely to conduct unethical behaviour and fifth, a person who can manage stress is likely to conduct unethical behaviour. All these issues have been highlighted by criminology studies (Sutherland, 1940) which indicate that fraud and misconduct in accounting are learned behaviours.

The Fraud Diamond Theory as illustrated in Figure 1 is applied as a model to understand earnings management behaviour is a fraud activity. As explained above, earnings management behaviour is legal 
when it is done within accounting standards (see, Bruns \& Merchant, 1990; Merchant \& Rockness, 1994; Parfet, 2000; Arya et al., 2003). Thus, it is deemed as an open opportunity for the management to practice earnings management without worry. However, when such practices lead to misconduct, it is considered a fraud. Further, incentive/ pressure faced by the management may force them to carry out earnings management behaviour. Cornett, Marcus, and Tehranian (2008) expressed that one of the motivations for managers to manage earnings is incentive which is in the form of a bonus. This finding is also verified by Healy (1985) who noted the effect of earnings management on bonus schemes. It is deduced that when the company's income reaches a certain level, it will affect stock prices and this will consequently increase the manager's wealth.

From the perspective of pressure, Wan Ismail et al. (2015) emphasised that the major scrutiny imposed on companies to perform well according to the practices of the code of conduct such as Shariah compliance is a form of pressure on the management. In their research, Wan Ismail et al. (2015) found that such companies tend to report higher earnings quality. However, due to the anticipation of stakeholders, it was observed that companies which had experienced losses and financial distress, may face the pressure of having to fulfil the stakeholders' demand. To accomplish this, such companies indulge in earnings management behaviour. Jones (2011) emphasised that managers may begin with earnings management but a failure to achieve the desired accounting results may cause these managers to commit fraudulent practices as a way of covering up. This outcome is endorsed by Hassan and Ahmed (2012). They detected that pressure such as meeting analysts' expectations can cause an increase in unethical behaviours within organisations.

Market anticipation and stakeholders' expectation of high valued Shariah-compliant companies are the essential components driving managers to perform well. With that rationale, managers need to shoulder various responsibilities such as providing high earnings quality for the organisation (Dadgar \& Naderi, 2009; Wan Ismail et al., 2015). In this regard, managers will do their best to fulfil these expectations and one way to do so is through earnings management behaviour. Undoubtedly, the managers' interpretation of the accounting standards and reporting and the managers' decision making on a transaction are areas which are difficult to measure unless the managers admit that they have acted with the intention to deceive (Marai \& Pavlović, 
2013). Therefore, these managers have the capability to be involved in unethical behaviours.

Through the application of the fraud diamond theory, it can be seen how managers of Shariah-compliant companies may commit earnings management as they make decisions based on internal and external factors. This study posits that the company's reputation, financial distress and performance are factors that can influence the earnings management behaviour of Shariah-compliant companies.

\section{Research Methodology}

\subsection{Population and Sample Selection}

The population for this study comprises 815 companies whose shares were listed in Bursa Malaysia in 2014. According to the SC (2014), over 82 per cent of these companies were recognised as Shariah-compliant. However, as the current study focusses on analysing company's reputation, only selected companies from the FTSE Bursa Malaysia 100 Index were examined. This index ranked the public listed companies (PLCs) by market capitalisation. Thus, with a specific objective and a target sample, this study used purposive-cluster sampling methods. The final sample is shown in Table 1.

Since the SAC carries out evaluations of Shariah-compliant companies twice a year, the list of Shariah-compliant companies within a year can change rapidly, either to include newly classified companies or to exclude previous companies. As a measure to ensure consistency for the categorisation of the companies as Shariah-compliant or nonShariah-compliant, this study classified a company as Shariah-compliant only if it has fulfilled the Shariah-compliant criteria throughout the period of 2010 to 2014.

From the FTSE Bursa Malaysia 100 Index (2010-2014), 27 companies were excluded from this study because their full data were not available. In taking the trail of previous studies (e.g., Kim et al., 2012; Wan Ismail et al., 2015), this study also chose to exclude companies from the financial industry because earnings of companies in the financial industry are reported differently hence, the measurement of earnings management would be different (see, Grougiou, Leventis, Dedoulis, \& Owusu-Ansah, 2014).

As a result, only 69 companies finally fulfilled the criteria to serve as the final study samples. They comprised 38 Shariah-compliant com- 
Table 1: Derivation of Sample and Industry Category

Panel A. Sample of Study

No.

Companies listed on Bursa Malaysia as of December 2014

815

Companies recognised as Shariah-compliant by SC as of November 2014

668

FTSE Bursa Malaysia 100 Index

100

Excluded companies (2010-2014)

(27)

Excluded companies in the financial industry

Final sample

Shariah-compliant

Non-Shariah-compliant

Panel B. Industry category

\begin{tabular}{lccr}
\hline Industry & Shariah-compliant & Non-Shariah-compliant & No. \\
\hline Trading/services & 11 & 9 & 20 \\
Plantation & 8 & 6 & 14 \\
Construction & 8 & 3 & 11 \\
Consumer product & 4 & 4 & 8 \\
Technology & 3 & 4 & 7 \\
Industrial product & 2 & 2 & 5 \\
Properties & 2 & & 4 \\
$\quad$ Total & & & 69 \\
\hline
\end{tabular}

panies and 31 non-Shariah-compliant companies. The purpose of giving focus to these two categories of companies was to understand the influence of Shariah practices. Panel B of Table 1 shows the number of companies categorised according to their industry. In total, there were 20 companies in trading/services and 14 companies in plantation. The lowest sample is the industrial product industry with only five companies and the properties industry consisting of four companies.

\subsection{Measures of Shariah-compliant}

To be recognised as Shariah-compliant, Malaysian PLCs need to experience three levels of screening established by the SAC. This is in accordance with the rulings of the Securities Commission of Malaysia which strives to evaluate and recognise these companies as Shariah-compliant companies or otherwise. The SAC adopts a two-tier 
quantitative approach which applies the business activity benchmark and the financial ratio benchmark. Following these activities, the companies will then be duly classified as Shariah-compliant or otherwise (see, SC, 2014). This study used an indicator variable that takes a value of 1 if the company is Shariah-compliant, and 0 if it is not.

\subsection{Measures of Earnings Management}

\subsubsection{Modified Jones Model (Discretionary Accruals)}

Literature has established a number of approaches to be used to estimate earnings management. This study applies the extensively used discretionary accruals (e.g., Jones 1991; Dechow et al., 1996; DeFond \& Subramanyam 1998; Kothari, Leone, \& Wasley, 2005; Mouselli, Jaafar, \& Hussainey, 2012) as one of the proxies. Discretionary accruals were estimated through the Modified Jones model. This was adjusted for performance (Dechow et al., 1996; Kothari et al., 2005). Various research have discussed the strengths and drawbacks of this model (e.g., Guay, Kothari, \& Watts, 1996; Young, 1999; Thomas \& Zhang, 2001; Lo, 2008; Dechow et al., 2010; DeFond, 2010). Despite its shortcomings, there is no alternative model that has a better solution to address the issue of estimating discretionary accruals (Botsari \& Meeks, 2008). According to Bartov, Gul and Tsui (2000) cross-sectional approach is the better measurement used to detect earnings manipulations. Consequently, this study also employed the cross-sectional approach of the Modified Jones model instead of the company-specific time-series approach (refer to Appendix A for details).

\subsubsection{Roychowdhury's Model (Real Activities Earnings Management)}

Real activities earnings management is defined as management actions that deviate from normal business practices and are undertaken for purposes of meeting certain earnings i.e., a deviation from companies' normal operational activities (Roychowdhury, 2006). Following recent researchers, this study also uses Roychowdhury's model which comprises four measures to detect real activities earnings management (e.g., Amoah, Anderson, Bonaparte, \& Muzorewa, 2017; Hinkel \& Hoffman, 2017; Wardhani \& Anggraenni, 2017). They are: (i) operating cash flows, (ii) production costs, (iii) expenses, and (iv) combined measures of real activities manipulation (refer Appendix B for details). 


\subsection{Measure of Reputation}

Prior studies employed the company's ranking in a certain list as the proxy for the company's reputation, for instance, Fortune Index (see, Fombrun \& Shanley, 1990; Melo \& Garrido-Morgado, 2012; Cao et al., 2012; Martínez-Ferrero et al., 2016). However, since this study is conducted in Malaysia, it is more appropriate to use the rank established in/for Malaysia. Thus, the study uses the FTSE Bursa Malaysia 100 Index, which ranks the PLCs based on their market capitalisation. Additionally, this study uses an indicator variable that takes a value of 1 for PLCs ranked 1-50 in the FTSE Bursa Malaysia 100 Index and a value of 0 for PLCs ranked 51-100.

\subsection{Measures of Financial Distress}

Three proxies were used to measure the company's financial distress such as: (i) company's losses, (ii) probability of bankruptcy, and (iii) probability of manipulation on tax expenses. The proxies are further elaborated.

\subsubsection{Company's Losses}

Companies that suffer losses tend to have low earnings quality (Wan Ismail et al., 2015). This implies that the possibility of the company engaging in earnings management is hypothetically high. Burgstahler and Dichev (1997) and Chih, Shen and Kang (2008) suggested that companies might manage reported earnings so as to avoid reporting losses. This study posits that a company's losses may influence its earnings management behaviour. Thus, the current study uses the indicator variable of 1 for the company that reported negative earnings at the end of the financial year and 0 otherwise.

\subsubsection{Altman Model}

Literature suggests that financially distressed companies have lower earnings quality (e.g., Dechow et al., 1996; Burgstahler \& Dichev, 1997; Saleh \& Ahmed, 2005). Despite this being so, Wan Ismail et al. (2015) did not find any significant result to suggest otherwise. Nevertheless, this study posits that the effect of financial distress may have an influence on the financial reporting of Malaysian companies. Thus, this study aims to analyse the relationship between the probability of bankruptcy and earnings management behaviour. Following previous literature, this 
study uses the emerging market model (Altman, Hartzell, \& Peck, 1998; Altman, 2005) to measure the probability of bankruptcy of a company (refer Appendix C for details).

\subsubsection{Effective Tax Rate}

Previous research suggests that a company may manipulate tax expenses to achieve earnings target (Omer, Bedard, \& Falsetta, 2006; Mulyadi \& Anwar, 2015). In this study, the effective tax rate is measured by comparing tax expenses with taxable income. Based on this, the current study posits that a company uses effective tax rate as one of the mechanisms to engage in earnings management practices. Hence, this study applies the indicator variable of 1 for a company that has paid tax expenses that are lower than taxable income and 0 otherwise.

\subsection{Measures of Financial Performance}

Extant literature has measured a company's financial performance by using return on assets (ROA) (Prior, Surroca, \& Tribó, 2008; Kim et al., 2012; Ibrahim et al., 2015; Wang et al., 2016; Alsaadi et al., 2017) and earnings per share (EPS) (Azeez, 2015; Kurmi \& Rakshit, 2017). This study uses both the ROA and EPS to proxy for financial performance.

\subsection{Measures of Control Variables}

Company size and leverage are widely used as a control variable in earnings management studies (see, Martínez-Ferrero et al., 2016; Lourenço, Rathke, Santana, \& Branco, 2018). It is argued that larger companies (measured by total assets) enjoy better reputations (Brammer \& Pavelin, 2004) and have lower costs of capital (Hail \& Leuz, 2006). This study uses company size which is measured by lagged total assets and level of leverage (e.g., Burgstahler, Hail, \& Leuz, 2006; Ali, Salleh, \& Hassan, 2008). Leverage is also used as one of the control variables in this study. The level of the company's leverage represents debts (Prior et al., 2008).

\subsection{Empirical Models}

This study employs four models to analyse the Shariah-compliant companies. Models 1 and 3 are used to analyse both the Shariah- 
compliant and non-Shariah-compliant companies but Models 2 and 4 are only used for examing Shariah-compliant companies. The models' assessments are formulated as follows:

$$
\begin{aligned}
M D J_{i t}= & a_{1} S H A_{i t}+a_{2} R E P_{i t}+a_{3} L O S_{i t}+a_{4} A L T_{i t}+ \\
& a_{5} E T R_{i t}+a_{6} R O A_{i t}+a_{7} E P S_{i t}+a_{8} S Z E_{i t}+a_{9} L E V_{i t} \\
M D J_{i t}= & a_{10} R E P_{i t}+a_{11} L O S_{i t}+a_{12} A L T_{i t}+a_{13} E T R_{i t}+ \\
& a_{14} R O A_{i t}+a_{15} E P S_{i t}+a_{16} S Z E_{i t}+a_{17} L E V_{i t} \\
C O M_{i t}= & a_{1} S H A_{i t}+a_{2} R E P_{i t}+a_{3} L O S_{i t}+a_{4} A L T_{i t}+ \\
& a_{5} E T R_{i t}+a_{6} R O A_{i t}+a_{7} E P S_{i t}+a_{8} S Z E_{i t}+a_{9} L E V_{i t} \\
C O M_{i t}= & a_{10} R E P_{i t}+a_{11} L O S_{i t}+a_{12} A L T_{i t}+a_{13} E T R_{i t}+ \\
& a_{14} R O A_{i t}+a_{15} E P S_{i t}+a_{16} S Z E_{i t}+a_{17} L E V_{i t}
\end{aligned}
$$

where

MDJ and COM are proxies for earnings management which are examined separately. $M D J$ represents discretionary accruals. It is a real number (either positive or negative value) of abnormal discretionary accruals which is computed through the cross-sectional approach of the Modified Jones model. COM represents real activities earnings management and it is a real number (either positive or negative value) taken from the level of abnormal cash flow from operations $(A b n O C F)$ minus the level of abnormal production costs. It is defined as the sum of the cost of goods sold and the change in inventories $(A b n P R D)$ plus the level of abnormal discretionary expenses (AbnDISEXP) which is defined as the sum of research and development expenses; advertising expenses; and selling, general and administrative expenses.

SHA represents Shariah-compliant and it is an indicator variable that takes a value of 1 if the company is Shariah-compliant, and 0 if otherwise as categorised by the SAC.

$R E P$ represents reputation and it is an indicator variable that takes a value of 1 for PLCs ranked 1-50 in the FTSE Bursa Malaysia 100 Index and 0 for PLCs ranked 50-100.

LOS represents losses and it is an indicator variable that takes a value of 1 for companies that reported negative earnings at the end of the financial year and 0 otherwise.

ALT represents financial distress measured using Altman Model. It is a scale variable that takes a value of 3 if the company's z-score is over 
2.6 and a value of 2 if the company's z-score is between 1.1 to 2.6 and a value score of 1 if the company's z-score is below 1.1 .

ETR represents effective tax rate and it is an indicator variable that takes a value of 1 if the company underpaid the tax expenses and 0 if otherwise.

ROA represents return on assets, which is a proxy for financial performance. It is measured by the company's net income that is scaled by the total assets.

EPS represents earnings per share, which is another proxy for financial performance. It is measured by the company's earnings that is scaled by the total shares.

SZE represents size of the company and it is measured by the log of total assets.

LEV represents leverage and it is proxied by total long-term debt, where $i$ and $t$ represent company and year, respectively.

\section{Findings}

\subsection{Descriptive Statistics}

Table 2 bearing Panel A and Panel B summarises the descriptive findings. Panel A shows the comparison variables in this study based on Shariah-compliant companies and non-Shariah-compliant companies. A significant difference by $p$-value $<.05$ on real activities earnings management $(C O M)$ is noted between the two categories of companies. Shariah-compliant companies lead in reputation $(R E P)$, effective tax rate $(E T R)$, and leverage $(L E V)$; they also have a significant difference with the non-Shariah-compliant companies.

Panel B in Table 2 shows the details about the study indicator variables. The samples in this study are comfortably balanced with 55.07 per cent Shariah-compliant companies and 44.93 per cent non-Shariahcompliant companies. The samples are also balanced for reputation, which is 46.38 per cent for companies ranked above 50 and 53.62 per cent for companies ranked 50 and below in the FTSE Bursa Malaysia 100 Index.

Table 3 shows the findings of the correlation coefficients for both the Spearman and Pearson analyses. Here, it is observed that a strong correlation exists amongst the variables with 1 per cent significant level. The highest was .602 which was between EPS and ROA with the $p$-value $<.01$ whereas the other variables were below .60. This finding 
explains that there is no serious multicollinearity problem between the variables used in this study. As Pallant (2007) suggested, coefficients that are higher than .70 is a sign of a serious multicollinearity problem.

Table 2: Descriptive Statistics

Panel A. Shariah-compliant versus Non-Shariah-compliant

\begin{tabular}{lcccccc}
\hline & \multicolumn{2}{l}{ Shariah-compliant } & & \multicolumn{2}{l}{ Non-Shariah-compliant } & \\
\cline { 2 - 3 } & Mean & SD & & Mean & SD & Mean difference \\
\hline MDJ & -.103 & .341 & .004 & .348 & -.107 \\
COM & -.052 & .210 & & -.110 & .311 & $.057^{* *}$ \\
REP & 1.526 & .501 & & 1.387 & .489 & $.139^{* * *}$ \\
LOS & .237 & .426 & & .368 & .484 & $-.131^{* * *}$ \\
ALT & 1.932 & .342 & & 1.826 & .458 & $.106^{* * *}$ \\
ETR & 1.189 & .968 & & 1.432 & .897 & $-.243^{* * *}$ \\
ROA & 9.237 & 1.275 & & 8.735 & 7.471 & .501 \\
EPS & .353 & .672 & .310 & .670 & .043 \\
SZE & 6.850 & .681 & 6.760 & .927 & .090 \\
LEV & .522 & .273 & .596 & .227 & $-.074^{*}$ \\
\hline
\end{tabular}

Panel B. Indicator Variables

\begin{tabular}{lccccr}
\hline & \multicolumn{2}{c}{ Yes (1) } & & \multicolumn{2}{c}{ No (0) } \\
\cline { 2 - 3 } \cline { 6 - 6 } & $\mathrm{n}$ & $(\%)$ & & $\mathrm{n}$ & $(\%)$ \\
\hline SHA & 190 & 55.07 & 155 & 44.93 \\
REP & 160 & 46.38 & & 185 & 53.62 \\
LOS & 102 & 29.57 & & 243 & 7.43 \\
ETR & 121 & 35.07 & 224 & 64.93 \\
\hline
\end{tabular}

Notes: $S H A=$ Shariah-compliant companies as categorised by the SAC, MDJ = earnings management measured by Modified Jones model, $C O M=$ real activities earnings management measured by Roychowdhury's model, REP = reputation, $L O S=$ losses, $A L T=$ financial distress measured by Altman model, ETR $=$ effective tax rate, $R O A=$ return on assets, $E P S=$ earnings per share, $S Z E=$ total assets, $L E V=$ total long-term.

Significance is based on a two-tailed test, ${ }^{*},{ }^{* *}$ and ${ }^{* * *}$ represent significance level at $10 \%, 5 \%$ and $1 \%$, respectively.

Observation is across the five-year period for 69 companies (345 financial reports) comprising 38 Shariah-compliant companies (190 financial reports) and 31 nonShariah-compliant companies (155 financial reports). 
Ibrahim Mohd Sabrun, Rusnah Muhamad, Haslinda Yusoff and Faizah Darus

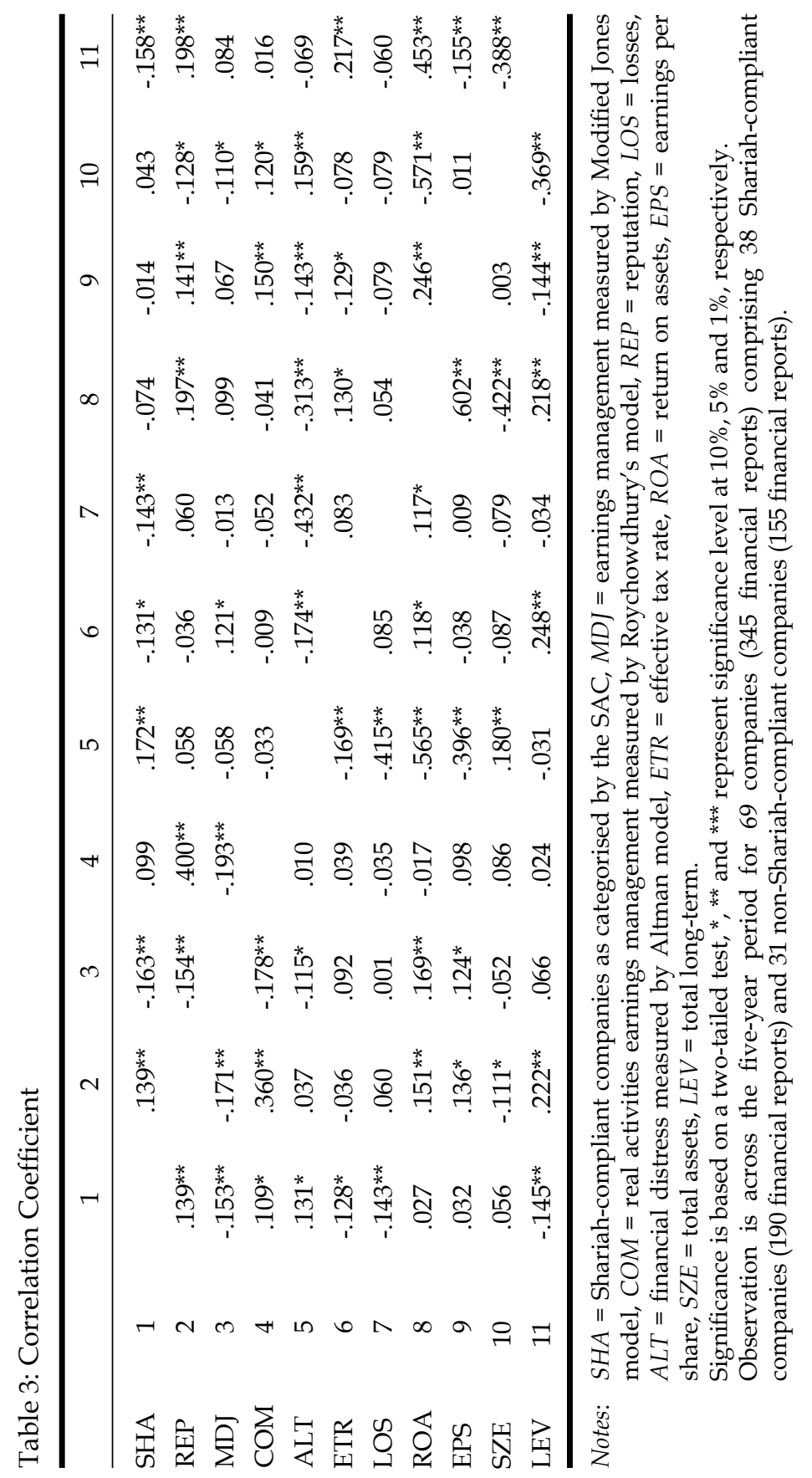




\subsection{Regression Analyses}

This study also examines earnings management by using the Modified Jones model (Jones, 1991; Dechow et al., 1996) and Roychowdhury's (2006) model separately (refer to Table 4). Models 1 and 3 were used to analyse both the Shariah-compliant and non-Shariah-compliant companies but Models 2 and 4 were only used for examing Shariahcompliant companies.

Table 4: Regression Results

\begin{tabular}{lccccc}
\hline & \multicolumn{2}{c}{ MDJ } & & \multicolumn{2}{c}{ COM } \\
& \multicolumn{2}{c}{ Coefficients (z-statistic) } & & \multicolumn{2}{c}{ Coefficients (z-statistic) } \\
\cline { 2 - 3 } \cline { 5 - 6 } & Model 1 & Model 2 & & Model 3 & Model 4 \\
\hline SHA & $-.087(-2.265)^{* *}$ & & & $.035(1.263)$ & \\
REP & $-.140(-3.583)^{* *}$ & $-.128(-2.422)^{* * *}$ & & $.198(7.009)^{* * *}$ & $.173(5.661)^{* * *}$ \\
LOS & $-.007(-.162)$ & $.079(1.225)$ & & $-.039(-1.199)$ & $-.103(-2.768)^{* * *}$ \\
ALT & $.032(.505)$ & $.187(1.554)$ & & $-.059(-1.299)$ & $.022(.317)$ \\
ETR & $.017(.815)$ & $.028(1.097)$ & & $.022(1.535)$ & $.022(1.489)$ \\
ROA & $.006(1.888)^{* *}$ & $.010(2.055)^{* *}$ & & $-.005(-1.975)^{* *}$ & $.004(1.373)$ \\
EPS & $.042(1.094)$ & $.071(1.231)$ & & $.044(1.585)$ & $-.060(-1.831)^{*}$ \\
SZE & $.011(.377)$ & $.092(1.890)^{*}$ & & $.024(1.199)$ & $.006(.199)$ \\
LEV & $.091(1.065)$ & $.197(1.819)^{*}$ & & $.003(.057)$ & $-.119(-1.901)^{* *}$ \\
\hline Industry & Included & Included & & Included & Included \\
Dummies & & & & & \\
Year & Included & Included & & Included & Included \\
Dummies & & & & & \\
Constant & $-.073(-.286)^{*}$ & $-1.170(-2.331)^{* *}$ & & $-.428(-2.330)^{* *}$ & $-.351(-1.212)^{*}$ \\
F-statistics & 3.904 & 2.289 & & 7.524 & 5.711 \\
Adjusted R $R^{2}$ & 0.071 & 0.092 & & 0.146 & 0.202 \\
\hline
\end{tabular}

Notes: $S H A=$ Shariah-compliant companies as categorised by the SAC, MDJ = earnings management measured by Modified Jones model, $C O M=$ real activities earnings management measured by Roychowdhury's model, $R E P=$ reputation, $L O S=$ losses, $A L T=$ financial distress measured by Altman model, ETR $=$ effective tax rate, $R O A=$ return on assets, $E P S=$ earnings per share, $S Z E=$ total assets, $L E V=$ total long-term.

Significance is based on a two-tailed test, ${ }^{*}, * *$ and ${ }^{* *}$ represent significance level at $10 \%, 5 \%$ and $1 \%$, respectively.

Observation is across the five-year period for 69 companies (345 financial reports) comprising 38 Shariah-compliant companies (190 financial reports) and 31 nonShariah-compliant companies (155 financial reports). 


\subsubsection{Shariah-compliant on Earnings Management}

The results in Table 4 show that $M D J$ has a negative significant relationship with SHA (Model 1 with coefficient -.087, z-stats -2.265, $p$-value<.05). This implies that Shariah-compliant companies were inclined towards engaging in earnings-decreasing activities. On the other hand, this study found that Shariah-compliant companies tend to manage their earnings by making alterations to the level of discretionary expenditures. However, COM and SHA relationship is statistically not significant (Model 3 with coefficient .035 and $z$-stats 1.263). The findings observed in the current study are different from those found by Kim et al. (2012). Although Kim et al. (2012) had used the same model they found that socially-responsible companies were less involved in real activities earnings management. Undoubtedly, Shariah-compliant companies are expected to promote good practices for the public good (maslahah) (Darus et al., 2013). Following Shariah values, these companies would be concerned with their stakeholders' interest and so would provide quality reporting. Hypothetically, they should not manipulate the accounting information for the sake of impressing their stakeholders by fulfilling the high expectations of the stakeholders. Based on the outcome of this study, hypothesis $\mathrm{H}_{1}$ could not be accepted or rejected because this study does not have enough evidence.

\subsubsection{Reputation on Earnings Management}

The results in Table 4 also show that REP has a significant relationship with $M D J$ and COM for Models 1 until 4 . This indicates that companies with high reputations engaged in earnings-decreasing practices (Model 1 with coefficient $-.140, z$-stats $-3.583, p$-value $<.05)$ and this includes Shariah-compliant companies (Model 2 with coefficient -.128, z-stats -2.422, $p$-value<.001). Also, Shariah-compliant companies had engaged in real activities earnings management (Model 4 with coefficient .173, z-stats 5.661, p-value<.001). These results echo the outcome which states that managers tend to engage in strategies including unethical conducts to preserve company's image and reputation (Roychowdhury, 2006). It was observed that the Shariah-compliant companies were no exception to unethical conducts. This finding implies that the Shariah-compliant status of companies is ineffective in deterring the management from engaging in unethical conducts such as earnings management practices. In this regard, hypothesis $\mathrm{H}_{2}$ is rejected. 


\subsubsection{Financial Distress on Earnings Management}

Shariah-compliant companies that suffer losses have a negative significant relationship with real activities earnings management (Model 4 with coefficient -.103, $z$-stats $-2.768, p$-value<.001). This may indicate that Shariah-compliant companies are highly likely to engage in earnings management behaviour by manipulating company's discretionary expenditures. In addition, Shariah-compliant companies are found to be involved in earnings management behaviour using accrual (Model 2 with coefficient .187 and $z$-stats 1.554) and discretionary expenditures (Model 4 with coefficient .022, z-stats .317) in moments when they are financially distressed but the relationship are statistically not significant. In the financial crisis of 2008, managements were found to engage in unethical behaviour for 'good reasons'. Farooq and AbdelBari (2015) and Chia et al. (2007) found evidence that companies committed earnings management during the financial crisis by reporting less than what they have.

Moreover, Shariah-compliant companies that underpaid taxes (i.e., companies have an effective tax rate) are found to have a positive relationship with earnings management behaviour (Model 2 with coefficient .028 and $z$-stats 1.097; Model 4 with coefficient .022, $z$-stats 1.489). However, the relationships are statistically not significant. These findings may be used to support the claim that a company may use effective tax rates to meet the earnings target (Comprix, Mills, \& Schmidt, 2012). To avoid political costs and attention from stakeholders, the management engaged in earnings management practices and forsake the ethical considerations (Yip, Van Staden, \& Cahan, 2011). From these results, hypothesis $\mathrm{H}_{3}$ can be partially accepted.

\subsubsection{Financial Performance on Earnings Management}

As predicted, companies with better financial performance (proxied by $R O A$ ) have a positive significant impact on earnings management activities, specifically in discretionary accruals (Model 1 with coefficient $.006, z$-stats $1.888, p$-value<.05). Shariah-compliant companies with high ROA are also found to be engaged in earnings management behaviour (Model 2, where the coefficient and $z$-stats increase to .010 and 2.055 respectively with similar $p$-value<.05). This may indicate that Shariahcompliant companies with better financial performance $(R O A)$ are more prone to practise accrual earnings management, particularly in earningsincreasing practices. In contrast, companies in general, are not involved 
in real activities earnings management (Model 3 with coefficient -.005, $z$-stats 1.975, $p$-value<.05).

The second proxy for financial performance, EPS was found to have a positive relationship with companies' earnings management activities. However, Shariah-compliant companies with low EPS have a small interest in practising real activities earnings management by reporting less on expenditures than what they actually have (Model 4 with coefficient -.060, $z$-stats 1.831, $p$-value<.10). The findings in this study support the notion that companies with better financial performance are more inclined towards earnings management practices. Hence, Shariahcompliant status has no effect in deterring companies from practising such unethical conduct (see, Hamdi \& Zarai, 2012; Alsaadi et al., 2017). From these results, hypothesis $\mathrm{H}_{4}$ can be partially accepted.

\subsubsection{Control Variables on Earnings Management}

Geraldina, Rossieta and Utama (2015) suggested that smaller companies have a higher tendency to engage in unethical conducts such as window dressing. Although higher total asset companies correspond to earningsincreasing (Model 2 with coefficient .092, z-stats 1.890, $p$-value<.10), Shariah-compliant companies with high leverage also tend to engage in earnings-increasing through accruals (Model 2 with coefficient .197, $z$-stats 1.819, $p$-value<.10). They managed the company's discretionary expenditures (Model 4 with coefficient -.119, z-stats -1.901, $p$-value<.05). Similar findings can also be observed in other recent research (see, Bozzolan, Fabrizi, Mallin, \& Michelon, 2015; Wang et al., 2016; Huang \& Sletten, 2017; Godsell, Welker, \& Zhang, 2017).

\section{Conclusion}

Islamic values and principles promoted in Shariah practices in business should deter the management from carrying out unethical conducts. However, this study found contrary results. Thus, it urges academicians and practitioners to improve Islamic accounting practices and reporting. The findings obtained from this study suggest that Shariah-compliant companies may not practise the Islamic ethical values holistically. Clearly, there are possibilities for Shariah-compliant companies to become involved in earnings management practices. The company's reputation, financial distress and financial performance are factors that motivate the companies to engage in such unethical practices. These 
findings can be explained by using the fraud diamond theory since management decision-making relies on the existence of opportunities, the capability of the manager, realisation and pressure/incentives.

In general, the findings generated from this study contribute to the augmentation of literature and it extends to the reporting practices related to earnings management activities. Nonetheless, this study is also constrained by several limitations. This study had examined the data of the top 100 PLCs from the years 2010 to 2014 only. Future research should consider extending this study to more current years and to examine more companies. Future researchers may want to explore measurements other than ROA and EPS to measure the company's financial performance. The results of this study also lead to another research question: if the earnings reported have been manipulated, how accurate is the ROA or EPS in representing a company's financial performance? This may be considered by future researchers.

\section{References}

Abdullah, S.N., Halim, N.F.C.A., \& Nelson, S.P. (2014). The impact of new regulations on earnings quality among Malaysian firms. International Journal of Economics, Management and Accounting, 22(2), 21-68.

Ali, S.M., Salleh, N.M., \& Hassan, M.S. (2008). Ownership structure and earnings management in Malaysian listed companies: The size effect. Asian Journal of Business and Accounting, 1(2), 89-116.

Alkdai, H.K.H., \& Hanefah, M.M. (2012). Audit committee characteristics and earnings management in Malaysian Shariah-compliant companies. Business and Management Review, 2(2), 52-61.

Alsaadi, A., Ebrahim, M.S., \& Jaafar, A. (2017). Corporate social responsibility, Shariah-compliance, and earnings quality. Journal of Financial Services Research, 51(2), 169-194. http:/ / dx.doi.org/10.1007/s10693-016-0263-0

Altman, E.I. (2005). An emerging market credit scoring system for corporate bonds. Emerging Markets Review, 6(4). 311-323, http://dx.doi.org/ 10.1016/j.ememar.2005.09.007

Altman, E.I., Hartzell, J., \& Peck, M. (1998). Emerging market corporate bonds - a scoring system. In R.M. Levich (Eds.), Emerging market capital flows: Proceedings of a conference held at the Stern School of Business (pp. 391-400). New York, NY: Springer. http:/ /dx.doi.org/10.1007/978-1-4615-6197-2_25

American Institute of Certified Public Accountants (AICPA). (2002). Statement on auditing standards (SAS) 99: Consideration of fraud in a financial statement audit. Available at https://www.aicpa.org

Amoah, N.Y., Anderson, A., Bonaparte, I., \& Muzorewa, S. (2017). Managerial opportunism and real activities manipulation: Evidence from option 
backdating firms. Review of Accounting and Finance, 16(3), 282-302. http:// dx.doi.org/10.1108/RAF-12-2014-0144

Arya, A., Glover, J.C., \& Sunder, S. (2003). Are unmanaged earnings always better for shareholders? Accounting Horizons, 17(s-1), 111-116. http:// dx.doi.org/ 10.2139/ssrn.322260

Azeez, A.A. (2015). Corporate governance and firm performance: Evidence from Sri Lanka. Journal of Finance \& Bank Management, 3(1), 180-189. http://dx.doi.org/10.15640/jfbm.v3n1a16

Bansal, P., \& Clelland, I.J. (2004). Talking trash: Legitimacy, impression management, and unsystematic risk in the context of the natural environment. The Academy of Management Journal, 47(1), 93-103. http:// dx.doi.org/10.2307/20159562

Bartov, E., Gul, F.A., \& Tsui, J.S. (2000). Discretionary-accruals models and audit qualifications. Journal of Accounting and Economics, 30(3), 421-452. http://dx.doi.org/10.1016/s0165-4101(01)00015-5

Botsari, A., \& Meeks, G. (2008). Do acquirers manage earnings prior to a share for share bid? Journal of Business Finance and Accounting, 35(5-6), 633-670. http://dx.doi.org/10.1111/j.1468-5957.2008.02091.x

Bozzolan, S., Fabrizi, M., Mallin, C.A., \& Michelon, G. (2015). Corporate social responsibility and earnings quality: International evidence. International Journal of Accounting, 50(4), 361-396. http://dx. doi.org/10.1016/j.intacc. 2015.10.003

Brammer, S., \& Pavelin, S. (2004). Building a good reputation. European Management Journal, 22(6), 704-713. http:/ / dx.doi.org/10.1016/j.emj.2004. 09.033

Bruns Jr, W.J., \& Merchant, K.A. (1990). The dangerous morality of managing earnings. Strategic Finance, 72(2), 22-25.

Burgstahler, D.C., Hail, L., \& Leuz, C. (2006). The importance of reporting incentives: Earnings management in European private and public firms. The Accounting Review, 81(5), 983-1016. http://dx.doi.org/10.2308/accr. 2006.81.5.983

Burgstahler, D., \& Dichev, I. (1997). Earnings management to avoid earnings decreases and losses. Journal of Accounting and Economics, 24(1), 99-126. http://dx.doi.org/10.1016/S0165-4101(97)00017-7

Cao, Y., Myers, L.A., \& Omer, T.C. (2012). Does company reputation matter for financial reporting quality? Evidence from restatements. Contemporary Accounting Research, 29(3), 956-990. http://dx.doi.org/10.1111/j.19113846.2011.01137.x

Chia, Y.M., Lapsley, I., \& Lee, H.W. (2007). Choice of auditors and earnings management during the Asian financial crisis. Managerial Auditing Journal, 22(2), 177-196. http:/ / dx.doi.org/10.1108/02686900710718672

Chih, H.L., Shen, C.H., \& Kang, F.C. (2008). Corporate social responsibility, investor protection, and earnings management: Some international evidence. Journal of Business Ethics, 79(1), 179-198. http://dx.doi.org/ $10.1007 /$ s10551-007-9383-7 
Comprix, J., Mills, L.F., \& Schmidt, A.P. (2012). Bias in quarterly estimates of annual effective tax rates and earnings management. The Journal of the American Taxation Association, 34(1), 31-53. http://dx.doi.org/10.2308/ atax-10152

Cornett, M., Marcus, A., \& Tehranian, H. (2008). Corporate governance and pay-for-performance: The impact of earnings management. Journal of Financial Economics, 87(2), 357-373. http://dx.doi.org/10.1016/j.jfineco. 2007.03.003

Dadgar, Y., \& Naderi, M. (2009). Corporate governance in capital market of Muslim countries (SSRN Working Paper Series). http://dx.doi.org/10.2139/ssrn. 1452818

Darus, F., Yusoff, H., Abang Naim, D.M., Mohamed Zain, M., Amran, A., Fauzi, H., \& Purwanto, Y. (2013). Islamic corporate social responsibilities (i-CSR) framework from perspective of Maqasid al-Syariah and Maslahah principles. Issues in Social and Environmental Accounting, 7(2), 102-112. http:/ / dx.doi.org/10.22164/isea.v7i2.77

DeAngelo, L.E. (1986). Accounting numbers as market valuation substitutes: A study of management buyouts of public stockholders. The Accounting Review, 61(3), 400-420.

Dechow, P., Ge, W., \& Schrand, C.M. (2010). Understanding earnings quality: A review of the proxies, their determinants and their consequences. Journal of Accounting and Economics, 50(2), 344-401. http://dx.doi.org/10.1016/j. jacceco.2010.09.001

Dechow, P.M., Sloan, R.G., \& Sweeney, A.P. (1996). Causes and consequences of earnings manipulation: An analysis of firms subject to enforcement actions by the SEC. Contemporary Accounting Research, 13(1), 1-36. http:// dx. doi.org/10.1111/j.1911-3846.1996.tb00489.x

DeFond, M.L. (2010). Earnings quality research: Advances, challenges and future research. Journal of Accounting and Economics, 50(2), 402-409. http:/ / dx.doi.org/10.1016/j.jacceco.2010.10.004

DeFond, M.L., \& Subramanyam, K.R. (1998). Auditor changes and discretionary accruals. Journal of Accounting and Economics, 25(1), 35-67. http://dx. doi. org/10.1016/s0165-4101(98)00018-4

Desai, M.A., \& Dharmapala, D. (2009). Earnings management, corporate tax shelters, and book-tax alignment. National Tax Journal, 62(1), 169-186. http:/ / dx.doi.org/10.17310/ntj.2009.1.08

Ding, R., Li, J., \& Wu, Z. (2018). Government affiliation, real earnings management, and firm performance: The case of privately held firms. Journal of Business Research, 83(C), 138-150. http://dx.doi.org/10.1016/j.jbusres. 2017.10.011

Du Jardin, P., Veganzones, D., \& Séverin, E. (2017). Forecasting corporate bankruptcy using accrual-based models. Computational Economics, 51(4), 1-37. http://dx.doi.org/10.1007/s10614-017-9681-9 
Dyreng, S.D., Mayew, W.J., \& Williams, C.D. (2012). Religious social norms and corporate financial reporting. Journal of Business Finance and Accounting, 39(7-8), 845-875. http://dx.doi.org/10.1111/j.1468-5957.2012.02295.x

Elliott, R.R., \& Willingham, J.J. (1980). Management fraud: Detection and deterrence. New York, NY: Petrocelli Books.

Farooq, O., \& AbdelBari, A. (2015). Earnings management behaviour of Shariah-compliant firms and non-Shariah-compliant firms: Evidence from the MENA region. Journal of Islamic Accounting and Business Research, 6(2), 173-188. http://dx. doi.org/10.1108/jiabr-07-2013-0021

Farrell, S. (2015, 21 July). The world's biggest accounting scandals. The Guardian. Available at https://www.theguardian.com

Filip, A., \& Raffournier, B. (2014). Financial crisis and earnings management: The European evidence. The International Journal of Accounting, 49(4), 455478. http://dx.doi.org/10.1016/j.intacc.2014.10.004

Fombrun, C., \& Shanley, M. (1990). What's in a name? Reputation building and corporate strategy. Academy of Management Journal, 33(2), 233-258. http:// dx.doi.org/10.2307/256324

Francis, J., Nanda, D., \& Olsson, P. (2008). Voluntary disclosure, earnings quality, and cost of capital. Journal of Accounting Research, 46(1), 53-99. http://dx.doi.org/10.1111/j.1475-679x.2008.00267.x

Franceschetti, B.M. (2018a). Does financial crisis cause earnings management? In B.M. Franceschetti, Financial crises and earnings management behavior (pp. 119-161). Cham, Germany: Springer. http://dx.doi.org/10.1007/978-3319-54121-1_5

Franceschetti, B.M. (2018b). Financial crisis as a major cause of earnings management: Theoretical background and literature review. In B.M. Franceschetti, Financial crises and earnings management behavior (pp. 103-117). Cham, Germany: Springer. http://dx. doi.org/10.1007/978-3-319-54121-1_4

Geraldina, I., Rossieta, H., \& Utama, S. (2015). Motives of customer deposits window-dressing in Indonesian commercial banks. Asian Journal of Business and Accounting, 8(2), 67-90.

Godsell, D., Welker, M., \& Zhang, N. (2017). Earnings management during antidumping investigations in Europe: Sample-wide and cross-sectional evidence. Journal of Accounting Research, 55(2), 407-457. http://dx. doi. org/10.1111/1475-679x.12166

Gordon, J.N. (2002). What Enron means for the management and control of the modern business corporation: Some initial reflections. University of Chicago Law Review, 69(3), 1233-1250. http:/ / dx.doi.org/10.2307/1600646

Grant, C.T., DePree Jr, C.M., \& Grant, G.H. (2000). Earnings management and the abuse of materiality. Journal of Accountancy, 190(3), 41-44.

Grougiou, V., Leventis, S., Dedoulis, E., \& Owusu-Ansah, S. (2014). Corporate social responsibility and earnings management in US banks. Accounting Forum, 38(3), 155-169. http://dx.doi.org/10.1016/j.accfor.2014.05.003 
Guay, W.R., Kothari, S.P., \& Watts, R.L. (1996). A market-based evaluation of discretionary accrual models. Journal of Accounting Research, 34, 83-105. http:/ / dx.doi.org/10.2307/2491427

Guyot, A. (2011). Efficiency and dynamics of Islamic investment: Evidence of geopolitical effects on Dow Jones Islamic market indexes. Emerging Markets Finance and Trade, 47(6), 24-45. http:/ /dx.doi.org/10.2753/ree1540496x470602

Hail, L., \& Leuz, C. (2006). International differences in the cost of equity capital: Do legal institutions and securities regulation matter? Journal of Accounting Research, 44(3), 485-531. http:/ / dx.doi.org/10.1111/j.1475-679x.2006.00209.x

Hamdi, F.M., \& Zarai, M.A. (2012). Earnings management to avoid earnings decreases and losses: Empirical evidence from Islamic banking industry. Research Journal of Finance and Accounting, 3(3), 88-107.

Hassan, S., \& Ahmed, A. (2012). Corporate governance, earnings management and financial performance: A case of Nigerian manufacturing firms. American International Journal of Contemporary Research, 2(7), 214-226.

Healy, P.M. (1985). The effect of bonus schemes on accounting decisions. Journal of Accounting and Economics, 7(1-3), 85-107. http://dx.doi.org/ 10.1016/0165-4101(85)90029-1

Healy, P.M., \& Palepu, K.G. (2003). The fall of Enron. The Journal of Economic Perspectives, 17(2), 3-26. http:/ / dx.doi.org/10.1257/089533003765888403

Hemingway, C.A., \& Maclagan, P.W. (2004). Managers' personal values as drivers of corporate social responsibility. Journal of Business Ethics, 50(1), 33-44. http:/ / dx.doi.org/10.1023/b:busi.0000020964.80208.c9

Hinkel, T.P., \& Hoffman, B.W. (2017). Meeting earnings benchmarks via real activities manipulation: Debt market effects. Journal of Accounting, Auditing and Finance, 1-30. http:/ / dx.doi.org/10.1177/0148558X17742568

Hossain, D.M., Karim, M.K.N.A., \& Eddine, C.O.H. (2014). Earnings Management and Islam. Labuan e-Journal of Muamalat and Society, 8, 87-97.

Huang, P., Louwers, T.J., Moffitt, J.S., \& Zhang, Y. (2008). Ethical management, corporate governance, and abnormal accruals. Journal of Business Ethics, 83(3), 469-487. http:/ / dx.doi.org/10.1007/s10551-007-9632-9

Huang, S., \& Sletten, E. (2017). Does litigation encourage or deter real earnings management? SSRN Electronic Journal. http://dx.doi.org/10.2139/ssrn. 2970311

Ibrahim, M.S, Darus, F., Yusoff, H., \& Muhamad, R. (2015). Analysis of earnings management practices and sustainability reporting for corporations that offer Islamic products \& services. Procedia Economics and Finance, 28, 176182. http:/ / dx.doi.org/10.1016/s2212-5671(15)01098-9

Jaggi, B., \& Lee, P. (2002). Earnings management response to debt covenant violations and debt restructuring. Journal of Accounting, Auditing and Finance, 17(4), 295-324. http:/ / dx.doi.org/10.1177/0148558x0201700402

Johnson, E.N., Fleischman, G.M., Valentine, S., \& Walker, K.B. (2012). Managers' ethical evaluations of earnings management and its consequences. 
Contemporary Accounting Research, 29(3), 910-927. http://dx.doi.org/ 10.1111/j.1911-3846.2011.01135.x

Jones, J.J. (1991). Earnings management during import relief investigations. Journal of Accounting Research, 29(2), 193-228. http://dx.doi.org/10.2307/ 2491047

Jones, M.J. (2011). Creative accounting, fraud and international accounting scandals. Chicester, England: John Wiley \& Sons.

Kaplan, S.E. (2001). Ethically related judgments by observers of earnings management. Journal of Business Ethics, 32(4), 285-298. http://dx.doi. org/10.1023/A:1010600802029

Kennedy, E.J., \& Lawton, L. (1998). Religiousness and business ethics. Journal of Business Ethics, 17(2), 163-175. http:/ / dx.doi.org/10.1023/ A:1005747511116

Kim, Y., Park, M.S., \& Wier, B. (2012). Is earnings quality associated with corporate social responsibility? The Accounting Review, 87(3), 761-796. http://dx.doi.org/10.2308/accr-10209

Kothari, S.P., Leone, A.J., \& Wasley, C.E. (2005). Performance matched discretionary accrual measures. Journal of Accounting and Economics, 39(1), 163-197. http://dx.doi.org/10.1016/j.jacceco.2004.11.002

Kurmi, M.K., \& Rakshit, D. (2017). Information content of EVA and traditional accounting based financial performance measures in explaining corporation's change of market value. International Journal of Research in Finance and Marketing, 7(2), 1-14.

Lee, T.A., Ingram, R.W., \& Howard, T.P. (1999). The difference between earnings and operating cash flow as an indicator of financial reporting fraud. Contemporary Accounting Research, 16(4), 749-786. http://dx.doi. org/10.1111/j.1911-3846.1999.tb00603.x

Li, F., Abeysekera, I., \& Ma, S. (2011). Earnings management and the effect of earnings quality in relation to stress level and bankruptcy level of Chinese listed firms. Corporate Ownership and Control, 9(1-3), 366-391. http:// dx.doi.org/10.22495/cocv9i1c3art2

Li, H., Pincus, M., \& Rego, S.O. (2008). Market reaction to events surrounding the Sarbanes-Oxley Act of 2002 and earnings management. The Journal of Law and Economics, 51(1), 111-134. http://dx.doi.org/10.1086/588597

Lo, K. (2008). Earnings management and earnings quality. Journal of Accounting and Economics, 45(2), 350-357. http://dx.doi.org/10.1016/j.jacceco.2007. 08.002

Longenecker, J.G., McKinney, J.A., \& Moore, C.W. (2004). Religious intensity, evangelical Christianity, and business ethics: An empirical study. Journal of Business Ethics, 55(4), 371-384. http://dx.doi.org/10.1007/s10551-0040990-2

Loomis, C.J. (1999). Lies, damned lies, and managed earnings the crackdown is here. The nation's top earnings cop has put corporate America on notice: Quit cooking the books. Cross the line, you may do time. Fortune, 140(3), 74-92. 
Lourenço, I.C., Rathke, A., Santana, V., \& Branco, M.C. (2018). Corruption and earnings management in developed and emerging countries. Corporate Governance: The International Journal of Business in Society, 18(1), 35-51. http:/ / dx.doi.org/10.1108/CG-12-2016-0226

Marai, A., \& Pavlović, V. (2013). Earnings management vs financial reporting fraud - key features for distinguishing. Economics and Organization, 10(1), 39-47.

Martínez-Ferrero, J., Banerjee, S., \& García-Sánchez, I.M. (2016). Corporate social responsibility as a strategic shield against costs of earnings management practices. Journal of Business Ethics, 133(2), 305-324. http://dx.doi. org/10.1007/s10551-014-2399-x

Melo, T., \& Garrido-Morgado, A. (2012). Corporate reputation: A combination of social responsibility and industry. Corporate Social Responsibility and Environmental Management, 19(1), 11-31. http:/ / dx.doi.org/10.1002/csr.260

Merchant, K.A., \& Rockness, J. (1994). The ethics of managing earnings: An empirical investigation. Journal of Accounting and Public Policy, 13(1), 79-94. http:/ / dx.doi.org/10.1016/0278-4254(94)90013-2

Mohamad, M.H.S., Abdul Rashid, H.M., \& Mohammed Shawtari, F.A. (2012). Corporate governance and earnings management in Malaysian government linked companies: The impact of GLCs' transformation policy. Asian Review of Accounting, 20(3), 241-258. http:/ / dx.doi.org/10.1108/13217341211263283

Mouselli, S., Jaafar, A., \& Hussainey, K. (2012). Accruals quality vis-à-vis disclosure quality: Substitutes or complements? British Accounting Review, 44(1), 36-46. http:/ / dx.doi.org/10.1016/j.bar.2011.12.004

Mulyadi, M.S., \& Anwar, Y. (2015). Corporate governance, earnings management and tax management. Procedia - Social and Behavioral Sciences, 177, 363-366. http:/ / dx.doi.org/10.1016/j.sbspro.2015.02.361

Noreen, E. (1988). The economics of ethics: A new perspective on agency theory. Accounting, Organizations and Society, 13(4), 359-369. http://dx.doi. org/10.1016/0361-3682(88)90010-4

Omar, N., Koya, R.K., Sanusi, Z.M., \& Shafie, N.A. (2014). Financial statement fraud: A case examination using Beneish Model and ratio analysis. International Journal of Trade, Economics and Finance, 5(2), 184-186. http:// dx. doi.org/10.7763/ijtef.2014.v5.367

Omer, T.C., Bedard, J.C., \& Falsetta, D. (2006). Auditor-provided tax services: The effects of a changing regulatory environment. The Accounting Review, 81(5), 1095-1117. http:/ / dx.doi.org/10.2308/accr.2006.81.5.1095

Orlitzky, M., Schmidt, F.L., \& Rynes, S.L. (2003). Corporate social and financial performance: A meta-analysis. Organization Studies, 24(3), 403-441. http:// dx. doi.org/10.1177/0170840603024003910

Pallant, J. (2007). SPSS survival manual: A step by step guide to data analysis using SPSS for windows (version 15). Sydney, NSW: Allen and Unwin.

Parfet, W.U. (2000). Accounting subjectivity and earnings management: A preparer perspective. Accounting Horizons, 14(4), 481-488. http://dx.doi. org/10.2308/acch.2000.14.4.481 
Perez, D., Salas-Fumas, V., \& Saurina, J. (2008). Earnings and capital management in alternative loan loss provision regulatory regimes. European Accounting Review, 17(3), 423-445. http:/ /dx.doi/org/10.1080/09638180802016742

Perols, J.L., \& Lougee, B.A. (2011). The relation between earnings management and financial statement fraud. Advances in Accounting, 27(1), 39-53, http:/ / dx.doi.org/10.1016/j.adiac.2010.10.004

Pierre, K.St., \& Anderson, J.A. (1984). An analysis of the factors associated with lawsuits against public accountants. The Accounting Review, 59(2), 242-263.

PricewaterhouseCoopers (PwC) (2013). Islamic finance - creating value. Available at https:/ / www.pwc.com

Prior, D., Surroca, J., \& Tribó, J.A. (2008). Are socially responsible managers really ethical? Exploring the relationship between earnings management and corporate social responsibility. Corporate Governance: An International Review, 16(3), 160-177. http:/ / dx.doi.org/10.1111/j.1467-8683.2008.00678.x Rawls, J. (1972). A theory of justice. Oxford: Oxford University Press.

Rice, G. (1999). Islamic ethics and the implications for business. Journal of Business Ethics, 18(4), 345-358. http:/ / dx.doi.org/10.1023/ A:1005711414306

Ronen, J., \& Yaari, V. (2008). Earnings management: Emerging insights in theory, practice, and research. New York, NY: Springer.

Roychowdhury, S. (2006). Earnings management through real activities manipulation. Journal of Accounting and Economics, 42(3), 335-337. http:/ / dx.doi.org/10.1016/j.jacceco.2006.01.002

Saleh, N.M., \& Ahmed, K. (2005). Earnings management of distressed firms during debt renegotiation. Accounting and Business Research, 35(1), 69-86. http:/ /dx.doi.org/10.1080/00014788.2005.9729663

Schipper, K. (1989). Commentary on earnings management. Accounting Horizons, 3(4), 91-102.

Securities Commission Malaysia (SC) (2014). List of Shariah-compliant securities by SC's Shariah Advisory Council. Available at https://www.sc.com.my

Securities Commission Malaysia (SC) (2015). Malaysian capital market grew to RM2.76 trillion in 2014. Available at https:/ / www.sc.com.my

Septiari, D., \& Maruli, M. (2017). Earnings management behaviour: The role of pressure on behaviour performance. Asian Journal of Business and Accounting, 10(2), 137-163.

Sheikh Obid, S.N., \& Demikha, L. (2011). Earnings management: Islamic perspective. Asia Pacific Journal of Accounting and Finance, 2(1), 77-89.

Solomon, R.C. (1992). Corporate roles, personal virtues: An Aristotelean approach to business ethics. Business Ethics Quarterly, 2(3), 317-339. http:/ / dx.doi.org/10.2307/3857536

Sutherland, E.H. (1940). White-collar criminality. American Sociological Review, 5(1), 1-12. http:/ / dx.doi.org/10.2307/2083937

Thomas, J., \& Zhang, X.J. (2001). Identifying unexpected accruals: A comparison of current approaches. Journal of Accounting and Public Policy, 19(45), 347-376. http:/ / dx.doi.org/10.1016/s0278-4254(00)00016-8 
U.S. Securities and Exchange Commission (SEC) (2011). SEC charges Satyam Computer Services with financial fraud. Available at https:/ / www.sec.gov/

Vinciguerra, B., \& O'Reilly-Allen, M. (2004). An examination of factors influencing managers' and auditors' assessments of the appropriateness of an accounting treatment and earnings management intentions. American Business Review, 22(1), 78-87.

Vladu, A.B., Amat, O., \& Cuzdriorean, D.D. (2017). Truthfulness in accounting: How to discriminate accounting manipulators from non-manipulators. Journal of Business Ethics, 140(4), 633-648. http://dx.doi.org/10.1007/ s10551-016-3048-3

Wallace, W.A. (1995). Auditing. Cincinnati, OH: South-Western College Publishing.

Wan Ismail, W.A., Kamarudin, K.A., \& Sarman, S.R. (2015). The quality of earnings in shariah-compliant companies: Evidence from Malaysia. Journal of Islamic Accounting and Business Research, 6(1), 19-41. http://dx.doi.org/ 10.1108/jiabr-03-2013-0005

Wang, X., Cao, F., \& Ye, K. (2016). Mandatory corporate social responsibility (CSR) reporting and financial reporting quality: Evidence from a quasinatural experiment. Journal of Business Ethics, 149(7), 1-22. http://dx. doi. org/10.1007/s10551-016-3296-2

Wardhani, R., \& Anggraenni, M. (2017). The effect of leverage and IFRS convergence on earnings management through real activities manipulation in Asia. Asian Journal of Business and Accounting, 10(1), 87-125.

Weil, R.L. (2009). Quality of earnings and earnings management: A primer for audit committee members. The American Institute of Certified Public Accountants (AICPA), 1-3.

Wolfe, D.T., \& Hermanson, D.R. (2004). The fraud diamond: Considering the four elements of fraud. The CPA Journal, 74(12), 38-42.

Yip, E., Van Staden, C., \& Cahan, S. (2011). Corporate social responsibility reporting and earnings management: The role of political costs. Australasian Accounting Business and Finance Journal, 5(3), 17-34.

Young, S. (1999). Systematic measurement error in the estimation of discretionary accruals: An evaluation of alternative modelling procedures. Journal of Business Finance and Accounting, 26(7-8), 833-862. http://dx.doi. org/10.1111/1468-5957.00277

Zahra, S.A., Priem, R.L., \& Rasheed, A.A. (2005). The antecedents and consequences of top management fraud. Journal of Management, 31(6), 803-828. http://dx.doi.org/10.1177/0149206305279598 


\section{Appendices}

Appendix A: Modified Jones Model

$$
\begin{aligned}
& T A C_{i t}=\left(\Delta C A_{i t}-\Delta C S H_{i t}\right)-\left(\Delta C L_{i t}-\Delta S T D_{i t}\right) \\
& \left(\frac{T A C_{i t}}{T A_{i, t-1}}\right)=\alpha_{1}\left(\frac{1}{T A_{i, t-1}}\right)+\alpha_{2}\left(\frac{\Delta R E V_{i t}-\Delta R E C_{i t}}{T A_{i, t-1}}\right)+\alpha_{3}\left(\frac{E R N_{i, t-1}}{T A_{i, t-1}}\right)+\varepsilon_{i t} \\
& N D A C_{i t}=\hat{\alpha}_{1}\left(\frac{1}{T A_{i, t-1}}\right)+\hat{\alpha}_{2}\left(\frac{\Delta R E V_{i t}-\Delta R E C_{i t}}{T A_{i, t-1}}\right)+\hat{\alpha}_{3}\left(\frac{E R N_{i t}}{T A_{i, t-1}}\right) \\
& D A C_{i t}=\left(\frac{1}{T A_{i, t-1}}\right)-N D A C_{i t}
\end{aligned}
$$

where TAC represents the total accrual, NDAC represents the nondiscretionary accrual, $D A C$ represents the discretionary accrual. $\triangle C A$ represents change in the company's current assets, $\triangle C S H$ represents change in cash, $\triangle C L$ represents change in current liabilities, $\triangle S T D$ represents change in short-term debt, TA represents total assets, $\triangle R E V$ represents change in revenue, $\triangle R E C$ represents change in receivables, $E R N$ represents earnings, $\hat{\alpha}$ is coefficient value, $\varepsilon$ is error term, $i$ is company and $t$ is year, respectively. Equation 1 is used to calculate the total accrual (TAC). Equations 2 to 4 are used to separate nondiscretionary accruals and discretionary accruals. The coefficient $\mathrm{a}_{1}, \mathrm{a}_{2}$ and $\mathrm{a}_{3}$ are used into the Equation 3 tested using ordinary least squares (OLS) regression. This study uses the real number (is either positive or negative value) of discretionary accruals as the key analysis on earnings management practices. It can be either earnings-increasing (positive value) or earnings-decreasing (negative value) accruals (Kim et al., 2012).

\section{Appendix B: Roychowdhury's Model}

$$
\begin{aligned}
& \left(\frac{O C F_{i t}}{T A_{i, t-1}}\right)=\alpha_{4}\left(\frac{1}{T A_{i, t-1}}\right)+\alpha_{5}\left(\frac{R E V_{i t}}{T A_{i, t-1}}\right)+\alpha_{6}\left(\frac{\Delta R E V_{i t}}{T A_{i, t-1}}\right)+\varepsilon_{i t} \\
& \left(\frac{C O G S_{i t}}{T A_{i, t-1}}\right)=\alpha_{7}\left(\frac{1}{T A_{i, t-1}}\right)+\alpha_{8}\left(\frac{R E V_{i t}}{T A_{i, t-1}}\right)+\varepsilon_{i t}
\end{aligned}
$$




$$
\begin{aligned}
& \left(\frac{\Delta I N V_{i t}}{T A_{i, t-1}}\right)=\alpha_{9}\left(\frac{1}{T A_{i, t-1}}\right)+\alpha_{10}\left(\frac{\Delta R E V_{i t}}{T A_{i, t-1}}\right)+\alpha_{11}\left(\frac{\Delta R E V_{i, t-1}}{T A_{i, t-1}}\right)+\varepsilon_{i t} \\
& \left(\frac{P R D_{i t}}{T A_{i, t-1}}\right)=\alpha_{12}\left(\frac{1}{T A_{i, t-1}}\right)+\alpha_{13}\left(\frac{R E V_{i t}}{T A_{i, t-1}}\right)+\alpha_{14}\left(\frac{\Delta R E V_{i t}}{T A_{i, t-1}}\right)+\alpha_{15}\left(\frac{\Delta R E V_{i, t-1}}{T A_{i, t-1}}\right)+\varepsilon_{i t} \\
& \left(\frac{D I S E X P_{i t}}{T A_{i, t-1}}\right)=\alpha_{16}\left(\frac{1}{T A_{i, t-1}}\right)+\alpha_{17}\left(\frac{R E V_{i t}}{T A_{i, t-1}}\right)+\varepsilon_{i t} \\
& C O M={ }^{A b n} O C F-{ }^{A b n} P R D+{ }^{A b n} D I S E X P
\end{aligned}
$$

where OCF represents company's operating cash flow, REV represents company's revenue, $\triangle R E V$ represents change in revenue, $T A$ represents total assets, COGS represents cost of goods sold, $\triangle I N V$ represents change in inventories, PRD represents production costs, DISEXP represents discretionary expenses, $\varepsilon$ is error term, $i$ is company and $t$ is year, respectively. Actual operating cash flow minus its abnormal level is calculated using estimated coefficient in Equation 1. Production costs are defined as the sum of the cost of goods sold and changes in inventory. Equation 2 is a linear function of contemporaneous sales to measure the level of abnormality in the cost of goods sold. Equation 3 is a linear function of the contemporaneous and lagged change in the sale. It is to measure the level of abnormality in inventory. Then, by using Equations 2 and 3, production costs are the sum of the cost of goods sold and changes in inventory. The normal level of production costs is estimated using Equation 4. The normal level of discretionary expenses is the sum of research and development expenses, advertising expenses, selling, general and administrative expenses using the following linear function in Equation 5. Finally, Equation 6 is used to determine the real activities earnings management. Real activities earnings management take place when the management alters the level of discretionary expenditures, either by deviations from operating and investing activities and deviations from financing activities. This study uses the real number (either positive or negative value) as the alteration may increase (positive) and decrease (negative) expenditures value. 


\section{Appendix C: Altman Model for Emerging Market}

The $x 1$ is to examine the company's working

$$
x l=\left(\frac{C A_{i t}-C L_{i t}}{T A_{i t}}\right)
$$
capital to the total assets. This to measure the company's ability to manage liquidity.

The $x 2$ is to examine the retained earnings to

$$
x 2=\left(\frac{E R N_{i t}}{T A_{i t}}\right)
$$
total assets, to measure company's cumulative profitability.

The $x 3$ is to examine the company's ability to generate profits from its assets base. This to

$$
x 3=\left(\frac{E B I T_{i t}}{T A_{i t}}\right)
$$
measure the company's survivability and the level of productivity.

The $x 4$ is to examine stockholders' equity to

$$
x 4=\left(\frac{M V E_{i t}}{T L_{i t}}\right)
$$
total liabilities. A low score indicating high probabilities for bankruptcy.

$Z$-score $=3.25+6.56(x 1)+3.26(x 2)+6.72(x 3)+1.05(x 4)$

where $C A$ represents company's current assets, $C L$ represents current liabilities, TA represents total assets, ERN represents company's retained earnings, EBIT represents earnings before taxes and interest, $M V E$ represents the market value of equity, TL represents total liabilities, $i$ is company and $t$ is the year, respectively. According to Altman (2005), a Z-score over 2.6 indicates the company is healthy and financially sound, Z-score at between 1.1 to 2.6 indicates the company is in a deteriorated tenancy and further weaknesses will lead to a serious problem, Z-score below 1.1 indicates the company is unhealthy and in danger of insolvency. This study uses indicator variables of 3,2 and 1 for companies whose finance is healthy, deteriorating and unhealthy respectively. 